\title{
Biochar as a Multifunctional Component of the Environment-A Review
}

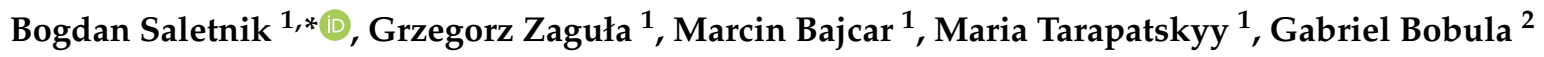 \\ and Czesław Puchalski 1 \\ 1 Department of Bioenergy Technology, Faculty of Biology and Agriculture, Rzeszow University, \\ Ćwiklińskiej 2D, 35-601 Rzeszow, Poland; g_zagula@ur.edu.pl (G.Z.); mbajcar@ur.edu.pl (M.B.); \\ czernicka.maria@gmail.com (M.T.); cpuchal@ur.edu.pl (C.P.) \\ 2 Faculty of Physical Education, Rzeszow University, Towarnickiego 3, 35-959 Rzeszow, Poland; \\ gbobula@ur.edu.pl \\ * Correspondence: bogdan.saletnik@urz.pl
}

Received: 4 February 2019; Accepted: 12 March 2019; Published: 18 March 2019

\begin{abstract}
The growing demand for electricity, caused by dynamic economic growth, leads to a decrease in the available non-renewable energy resources constituting the foundation of global power generation. A search for alternative sources of energy that can support conventional energy technologies utilizing fossil fuels is not only of key significance for the power industry but is also important from the point of view of environmental conservation and sustainable development. Plant biomass, with its specific chemical structure and high calorific value, is a promising renewable source of energy which can be utilized in numerous conversion processes, enabling the production of solid, liquid, and gaseous fuels. Methods of thermal biomass conversion include pyrolysis, i.e., a process allowing one to obtain a multifunctional product known as biochar. The article presents a review of information related to the broad uses of carbonization products. It also discusses the legal aspects and quality standards applicable to these materials. The paper draws attention to the lack of uniform legal and quality conditions, which would allow for a much better use of biochar. The review also aims to highlight the high potential for a use of biochar in different environments. The presented text attempts to emphasize the importance of biochar as an alternative to classic products used for energy, environmental and agricultural purposes.
\end{abstract}

Keywords: biochar; pyrolysis; environmental conservation; soil ameliorant

\section{Introduction}

In recent years, biochar and the wide range of its possible applications have been extensively investigated by researchers worldwide. In accordance with the definition specified by the International Biochar Initiative (IBI), biochar is a fine-grained product of carbonization, characterized by a high content of organic carbon and low susceptibility to degradation, which is obtained through the pyrolysis of biomass and biodegradable waste [1]. It is produced from organic matter as a result of pyrolysis, a process which is carried out in the absence of oxygen. Biochar can be utilized for energy-related purposes associated with environmental conservation and agriculture. The wide range of biochar applications is continuously expanding, mainly in such areas as industry, agriculture and operations related to the natural environment. It can be used as a soil additive, or added to fodder and silage, or applied in water treatment [2,3]. Biochar can also be used for the immobilization of contaminants from soil, and in sewage treatment; it can be applied as a supplementary material in composting and in methane fermentation processes [4-9]. Biochar application can be used as a filter 
for tar reduction in pyrolysis and gasification, as a fuel when pelletized, and also used as a substrate to produce hydrogen [10-12].

One of the ways to convert biomass is the gasification process, a state-of-the-art method of energetic use of biomass. The advantages of this process in relation to other methods are the possibilities of multi-directional use of the obtained product, namely the gas. Modern gasification methods make it possible to obtain two products: synthesis gas (syngas) being a mixture of gases $\left(\mathrm{H}_{2}, \mathrm{CO}, \mathrm{CO}_{2}, \mathrm{CH}_{4}\right)$ and residues in the form of ash. When classifying gasification processes, they can be divided using different criteria depending on reactor type, gasification factor, thermal relations, gasification process parameters (pressure, temperature). The first stage of the gasification process is drying the material, which can have up to $50 \%$ water content, at a temperature of $100-200{ }^{\circ} \mathrm{C}$. The next step is pyrolysis at increased temperatures $\left(200-600{ }^{\circ} \mathrm{C}\right)$ using an anaerobic atmosphere to release the volatile parts contained in biomass. Products of this stage are solid substances such as charcoal, liquid substances (tars, oils and gas water), flammable gas and aromatic hydrocarbons such as benzene, toluene. The last stage is gasification (temperature above $750^{\circ} \mathrm{C}$ ) of solid and liquid substances produced at pyrolysis. This is a series of exoand endothermal reactions that result in the production of flammable gas components [13-15]. Thermal processes of biomass (mainly the ones of lignocellulosic origin) processing also include torrefaction. The process is carried out in an anaerobic atmosphere at a temperature of $200-300{ }^{\circ} \mathrm{C}$ and the rate of temperature increase is in the range of $10-100{ }^{\circ} \mathrm{C} \mathrm{min}-1$. Given the long duration of the process and relatively low temperatures, this process is also called roasting or mild pyrolysis [16]. Biomass processed as a result of the torrefaction process acquires new physicochemical properties, especially important when used as a fuel for the power industry. Products of torrefaction are characterized by increased milling susceptibility and energy density and their properties resemble low calorific coals. A typical torrefaction process is characterized by loss of mass and chemical energy of the raw material used. When analyzing the mass/energy ratio, an increased concentration of chemical energy of the fuel obtained in relation to the raw material can be observed [17]. When analyzing environmental aspects, biochemical conversions have an important role. The products (fuels) produced by these technologies are biogas, thio-alcohols and biodiesel. The use of biochemical processes seems reasonable when biomass contains large amounts of water. One type of such transformation is alcoholic fermentation, which allows carbohydrates to be broken down under anaerobic conditions with the addition of yeasts. The product of this conversion is bioethanol. Liquid biofuels can also be produced using a biochemical process such as oil esterification, which makes it possible to obtain methyl esters. Methane fermentation, on the other hand, affects the decomposition of multi molecular organic substances under conditions of limited access to oxygen. In the results, we obtain products in the form of alcohols, lower organic acids, as well as methane and carbon dioxide [18].

Thermal biomass conversion methods include pyrolysis, i.e., thermochemical transformation of biomass occurring in anaerobic conditions or in the presence of a small amount of oxygen, insufficient for combustion. Pyrolysis generates carbonization products, i.e., a highly carbonized solid biomass substance, bio-oil, also referred to as pyrolysis oil, as well as gas [19]. Depending on the parameters applied we can distinguish slow (bio-carbonization), fast and moderate pyrolysis as well as gasification. Fast pyrolysis (temperature of $500{ }^{\circ} \mathrm{C}$ with the peak (ultimate) temperature maintained for $1 \mathrm{~s}$ ) produces approximately $12 \%$ of biochar. Slightly better results can be achieved by using moderate pyrolysis (temperature of $500{ }^{\circ} \mathrm{C}$, the ultimate temperature maintained for 10-20 s)—approximately $20 \%$ of biochar. The highest percentage of biochar, at a level of $35 \%$, may be obtained with the use of slow pyrolysis (at a temperature of $400-500{ }^{\circ} \mathrm{C}$ with the ultimate temperature maintained for 5-30 min.). The application of a high temperature, over $800{ }^{\circ} \mathrm{C}$, and a short duration of the process at the ultimate temperature (gasification) leads to a yield of biochar amounting to $10 \%$ [20,21]. The low biochar content may also be related to the presence of oxygen and water in the reactor. It should also be pointed out that by using the rate of biomass heating as a classification factor we can distinguish between fast and slow pyrolysis. Reference books state that the heating rate of $1-100{ }^{\circ} \mathrm{C} \mathrm{min}-1$ is used in slow pyrolysis, whereas reaching the temperature heating rate above $1000{ }^{\circ} \mathrm{C} \mathrm{min}^{-1}$ is characterized as fast pyrolysis [22]. 
The properties of biochar closely depend on the temperature of the pyrolysis process [23]. An increase in the temperature of pyrolysis leads to greater carbonification of the feedstock resulting in a higher carbon content and a decrease in the contents of hydrogen and oxygen [24]. The process of pyrolysis optimization towards obtaining a desired product should take into account the temperature of the reactor, rate of temperature increase, and duration of the process at the ultimate temperature. The authors emphasize relevant parameters of pyrolysis optimization in order to increase the utility of biochar as a high carbon material and at the same time cheap in production and generally available for application. This review presents an interdisciplinary approach to the topic of the importance of biochar in environmental, legal aspects of its application and quality standards.

\section{Biochar and its Properties}

Biochar may be produced from numerous materials of varied origins, e.g., energy crops, forest residues as well as agricultural residues [25-30]. Other materials used for biochar production include sewage sludge, waste from the food processing industries, e.g., oats previously subjected to fermentation, as well as poultry litter and cattle manure (Table 1) [31,32]. Importantly, the choice of feedstock for biochar production depends on e.g., economic and logistic factors as well as the parameters of the pyrolysis process itself and the types and properties of the applied substrates, e.g., water contents [21].

Table 1. Selected feedstocks used in biochar production [25-30].

\begin{tabular}{cc}
\hline Origin of Feedstocks & Type \\
\hline $\begin{array}{c}\text { Agriculture } \\
\text { Forest }\end{array}$ & $\begin{array}{c}\text { Energy crops, corncob, rice husk, sunflower husk, post-fermentation oats, bamboo, } \\
\text { bagasse, waste from olive oil production, straw, wheat husk, cattle manure, poultry litter }\end{array}$ \\
Waste & $\begin{array}{c}\text { Conifer bark, pellets from sawdust, peat, moss, beech timber, } \\
\text { Waste from tea factories, paper, sewage sludge, municipal organic waste }\end{array}$ \\
\hline
\end{tabular}

The most important properties of biochars include their chemical composition, stability, specific surface and porosity. Importantly, the chemical composition of biochars mainly depends on the chemical composition of the substrates used in biochar production. Biochars contain stable organic carbon, aromatic compounds, aliphatic compounds and ash [33]. Taking into account the type of biomass and parameters of thermal processing applied, the content of carbon in biochar may be in the range of $50-90 \%$, water $1-15 \%$, volatile substances up to $40 \%$ and mineral substances up to $5 \%$. Carbonization products have a neutral or alkaline $\mathrm{pH}$ and are highly resistant to microbiological degradation and decomposition; applied in the soil they are stable in terms of their chemical composition [21]. Their porous structure on the other hand contributes to improved sorption capacity of soils (Figure 1) [34].

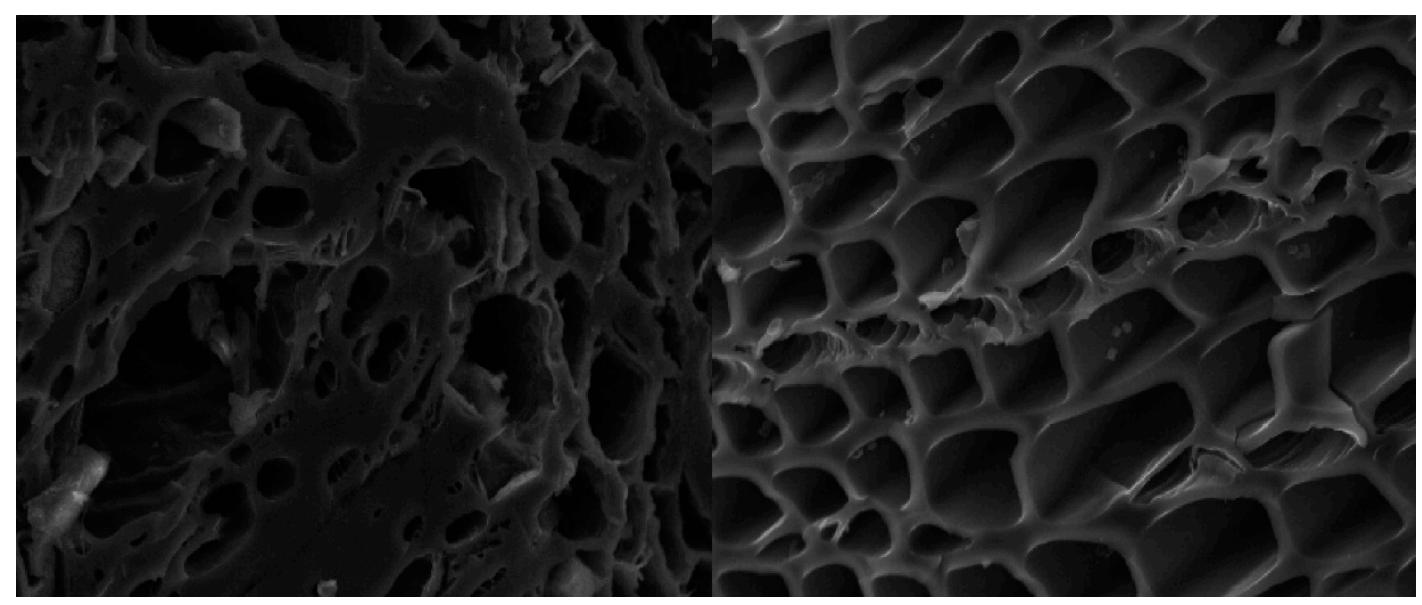

Figure 1. The porous structure of biochar [35]. 
Biomass pyrolysis conducted at higher temperatures may lead to an increased $\mathrm{pH}$ of the biochar. At lower temperatures it is possible to obtain biochar with higher ion-exchange capacity. Because of their physicochemical properties, biochars can be used for such purposes as soil carbon sequestration, the production of soil conditioner, as well as soil rehabilitation [21]. Table 2 presents some selected properties of biochars in relation to the feedstocks used and pyrolysis temperature applied.

Table 2. Selected properties of biochar, depending on the materials applied and the temperature of the pyrolysis process.

\begin{tabular}{|c|c|c|c|c|c|c|c|c|c|}
\hline $\begin{array}{c}\text { Feedstock for } \\
\text { Biochar Production }\end{array}$ & $\mathrm{pH}$ & $\underset{\mathrm{kg}^{-1}}{\mathrm{Cg}}$ & $\begin{array}{l}\mathrm{Ng}^{\mathrm{g}} \\
\mathrm{kg}^{-1}\end{array}$ & $\mathrm{C} / \mathrm{N}$ & $\underset{\mathrm{kg}^{-1}}{\mathrm{Pg}}$ & $\underset{\mathrm{kg}^{-1}}{\mathrm{Kg}}$ & $\begin{array}{c}\text { Ash } \\
\%\end{array}$ & $\begin{array}{c}\text { Temp. of } \\
\text { Pyrolysis } \\
\left({ }^{\circ} \mathrm{C}\right)\end{array}$ & References \\
\hline Acacia bark & 7.4 & 398 & 10.4 & 38 & - & - & - & $260-360$ & [36] \\
\hline Coconut & - & 690 & 9.4 & 73 & - & - & 3.38 & 500 & [37] \\
\hline Corn & - & 675 & 9.3 & 73 & - & 10.4 & - & 350 & \\
\hline Corn & - & 790 & 9.2 & 86 & - & 6.7 & - & 600 & [38] \\
\hline Green waste & 6.2 & 680 & 1.7 & 400 & 0.2 & 1 & - & 450 & [39] \\
\hline Peanut shells & - & 499 & 11.0 & 45 & 0.6 & 6.2 & - & 400 & [40] \\
\hline Pecan shells & 7.6 & 834 & 3.4 & 245 & - & - & 3.8 & 700 & [41] \\
\hline Pecan shells & - & 880 & 4.0 & 220 & - & - & - & 700 & [42] \\
\hline Rice straw & - & 490 & 13.2 & 37 & - & - & 9.54 & 500 & [37] \\
\hline Sewage sludge & - & 470 & 64 & 7 & 56 & - & 35 & 450 & [43] \\
\hline Sugarcane bagasse & - & 710 & 17.7 & 40 & - & - & 4.34 & 500 & [37] \\
\hline Eucalyptus wood & 7.0 & 824 & 5.7 & 144 & 0.6 & - & 0.23 & 350 & [44] \\
\hline Oak wood & - & 759 & 1.0 & 759 & - & 1.1 & - & 350 & [38] \\
\hline Oak wood & - & 884 & 1.2 & 737 & - & 2.2 & - & 600 & {$[38]$} \\
\hline
\end{tabular}

Different types of fuel, including waste, can be used for pyrolysis. The types of raw materials for pyrolysis can generally be divided into three groups: mine fuels, e.g., coal, biomass, e.g., wood, sewage sludge and plastics, e.g., tires. Each of these raw materials has different chemical composition and physical properties, which affect the quality of the pyrolysis products obtained. Biomass is a very universal raw material in its morphology and physical characteristics. Biomass material can be partially wet or dry, homogeneous or heterogeneous, of high density or of a loose structure, low or high ash content, high or low fragmentation [45]. This variety of properties of raw materials for biofuel production in gasification reactors is difficult and it is necessary to apply other processing measures focusing on the properties in question. Hence there is a large diversity of bioreactors used in biomass processing as well as a wide range of final products diversified in terms of properties determined by the conditions of the pyrolysis process and the type of bioreactor. Knowledge of the chemical structure and their behavior during the process of pyrolysis is extremely important from the point of view of application of optimal technological solutions, selection of appropriate parameters (temperature, process duration), process efficiency and environmental nuisance.

High heating rates promote cellulose and hemicellulose depolymerization reactions, minimizing the volatiles residence time inside the particle and secondary reactions. It also favors the volatiles cracking. So, the condensable gas release goes on quickly thus achieving high yields of bio-oil and the lowest production of char. Low temperatures and low heating rates promote intra-chain hydrogen bonds of cellulose functional groups, increasing the probability of collision to produce a dehydration reaction. For high heating rates, inter-chain hydrogen bonds are stronger achieving greater separation between the cellulose molecules and thus decreasing the possibility of collisions that facilitate the dehydration reaction. There are many reports in literature pointing out the importance of the effects of the heating rate on the yields of bio-oil and char [22,46,47].

The physical and chemical properties of the raw materials used in the process are the most important. The highest yields of carbonization products are obtained when raw materials with high lignin content are subjected to pyrolysis at moderate temperatures. Basically, biomass containing a significant amount of volatile substances offers a large amount of pyrolytic gas and bio-oil, and the presence of solid coal increases the efficiency of biochar production [19]. The moisture content of 
biomass has a significant impact on the heat transfer process and product distribution. Numerous experiments in the process of pyrolysis have confirmed that carbonization product's efficiency increases at low heating rates. During fast heating, the efficiency of volatile parts increases and less secondary reactions occur [48]. In the case of reactors with a high biochar production capacity, the fixed bed reactor and fast-moving fluidized bed reactors should be considered. In the case of slow pyrolysis, the use of a fixed bed allows the use of a large working surface of the reactor. Fluidized beds allow the process to be carried out much faster but are limited by volume for technological reasons [49].

\section{Legal Aspects and Quality Standards}

The term "biochar" does not appear in the legislation of the EU or Poland. The only European country which has adopted regulations relating to it is Switzerland. Considerations linked to biochar production and the wide range of its possible applications should however take into account the legal regulations on waste management, use of fertilizers and product safety [2].

Legal regulations fail to explicitly define the status of biochar, classifying it as a product, by-product, or waste [50-53]. In practice, biochar is perceived as waste, while in the literature it is most frequently described as a by-product of pyrolysis. The relevant EU and Polish regulations [54] define waste as "any substance or object which the holder discards, intends to discard or is required to discard". In accordance with the Waste Act, biochar produced from agricultural biomass wastes, or bio-wastes, may be classified as waste material produced as a result of a thermal conversion process. Accordingly, carbonization products should be treated as waste, however, biochar is not listed in the waste catalogue [55]. Article 14 of the Waste Act provides that "specific types of waste no longer have the status of waste if, following recovery, including recycling, they jointly meet specified conditions:

- the object or substance is commonly used for particular purposes,

- there is a market or demand for such objects or substances,

- the object or substance meets the technical requirements for applications related to specific purposes as well as the requirements set out in the rules and standards applicable to the product,

- $\quad$ use of the object or substance does not lead to negative consequences for human life or well-being or for the environment, as well as the requirements defined by regulations of the European Union" [56]. Given the above, biochar is no longer classified as waste.

In light of the regulations biochar can also be classified as a by-product, if it meets all of the following conditions: "further use of the object or the substance is certain; the object or substance may be used directly with no further processing other than normal industrial practice; the object or substance is produced as an integral part of a production process; the substance or object fulfils all relevant requirements, including legal, product-related, environmental and health protection requirements for the specific use of these substances or objects and their use will not lead to overall adverse environmental or human health impacts" [56]. Biochar can also be treated as a product, if it is the main product of a given process, and it has been produced from biomass obtained specifically for this purpose [53]. In a situation when biochar is treated as a product or by-product, the provisions of the Waste Act are not applicable; on the other hand, it is necessary to take into account other legal requirements (e.g., the regulations of the registration, evaluation, Authorization and restriction of chemicals (REACH) system) [57].

As regards EU laws, it can be concluded that the use of biochar in soils is not explicitly regulated or forbidden [53]. As an exception, Switzerland permits the use of biochar in agriculture provided that the requirements specified by the European Biochar Certificate (EBC) are complied with. The use of biochar as a soil ameliorant in the EU is subject to the provisions set forth by Regulation (EC) No 2003/2003 [58]. In Poland, in order to use biochar as a fertilizer or soil ameliorant it is necessary to complete a registration procedure and obtain approval from the Minister of Agriculture and Rural Development. Notably, these legal requirements are not applicable if biochar is used as a fertilizer in quantities necessary for experimental studies as well as in research and development projects [2]. 
Given the wide range of substrates used in the production of biochar, as well as the diverse conditions of thermal processing applied, and consequently the varied chemical composition of the final products, attempts have been made to regulate quality requirements related to carbonization products. It was necessary to take adequate steps and develop uniform guidelines and define quality requirements for biochar and substrates used in its production. As a result, global biochar organizations developed their own quality standards (biochar quality certificates):

- Biochar standards defined by the International Biochar Initiative (IBI), USA [1];

- European Biochar Certificate defined by the European Biochar Foundation [59];

- Biochar Quality Mandate developed by the British Biochar Foundation in the United Kingdom [60].

These standards present recommendations related to the substrates applied in the production of biochar, parameters of technological processes, requirements for biochar materials introduced into the soil as well as providing guidelines for the methodology of conducting measurements and analyses. Importantly, the requirements contained therein take the form of guidelines and they are not legally binding in the European Union member states [61]. Developed under the European Union Framework Program, the project entitled REFERTIL (reducing mineral fertilizers and chemicals use in agriculture by recycling treated organic waste as compost and biochar products) was designed to develop quality requirements for biochar to be adopted as recommendations for legal regulations relating to fertilizers [62].

The quality requirements defined for biochar ensure the safety of its soil-related applications, specify permissible contents of heavy metals, furans, polychlorinated biphenyls, dioxins and polycyclic aromatic hydrocarbons [63-65]. Table 3 summarizes and compares permissible levels of contaminants in biochar, as defined by the International Biochar Initiative (IBI), British Biochar Foundation (BQM), European Biochar Foundation (EBC) and under the REFERTIL project.

Table 3. The permissible content of contaminants in biochar, based on the existing quality standards $[1,59,60,62]$.

\begin{tabular}{|c|c|c|c|c|c|c|}
\hline \multirow{3}{*}{$\begin{array}{c}\text { Parameter } \\
\text { (mg kg }{ }^{-1} \text { of Dry Matter) }\end{array}$} & \multirow{3}{*}{ IBI } & \multicolumn{2}{|c|}{ BQM } & \multicolumn{2}{|c|}{ EBC } & \multirow{3}{*}{ REFERTIL } \\
\hline & & \multicolumn{4}{|c|}{ Type of Biochar } & \\
\hline & & High Grade & Standard & Premium & Basic & \\
\hline As & $13-100$ & 10 & 100 & 13 & 13 & 10 \\
\hline $\mathrm{Cd}$ & $1.4-39$ & 3 & 39 & 1 & 1.5 & 1.5 \\
\hline $\mathrm{Cr}$ & $93-1200$ & 15 & 100 & 80 & 90 & 100 \\
\hline $\mathrm{Cu}$ & $143-6000$ & 40 & 1500 & 100 & 1000 & 200 \\
\hline $\mathrm{Hg}$ & 1-17 & 1 & 17 & 1 & 1 & 1 \\
\hline $\mathrm{Ni}$ & $47-420$ & 10 & 600 & 30 & 50 & 50 \\
\hline $\mathrm{Pb}$ & $121-300$ & 60 & 500 & 120 & 150 & 120 \\
\hline $\mathrm{Zn}$ & $416-7400$ & 150 & 2800 & 400 & 400 & 600 \\
\hline Se & $2-200$ & 5 & 100 & - & - & - \\
\hline Mo & $5-75$ & 10 & 75 & - & - & - \\
\hline $\mathrm{F}$ & - & - & - & - & - & - \\
\hline WWA & $6-300$ & 20 & 20 & 4 & 12 & 6 \\
\hline PCB & $0.2-1$ & 0.5 & 0.5 & 0.2 & 0.2 & 0.2 \\
\hline $\begin{array}{l}\text { Dioxins and furans } \\
\quad\left(\mathrm{ng} \mathrm{kg}^{-1}\right)\end{array}$ & 20 & 20 & 20 & 20 & 20 & 20 \\
\hline
\end{tabular}

In Poland, the requirements related to the permissible contamination of organic and organic-mineral fertilizers, as well as crop enhancers are defined by the Regulation of the Minister of Agriculture and Rural Development of 18 June 2008 on the implementation of certain provisions of the Act on fertilizers and fertilization [66]. It specifies e.g., permissible contents of cadmium, lead, nickel, mercury, respectively at the levels of 5, 140, 60, $2 \mathrm{mg} \mathrm{kg}^{-1}$ of dry matter of the fertilizer or 
crop enhancer, yet it fails to take into account contaminations taking the form of polycyclic aromatic hydrocarbons or polychlorinated biphenyls.

\section{Biochar in Environmental Conservation}

The use of biochar in environmental protection falls within the scope of remediation of polluted soils, energy production, climate change aspects, waste management, sustainable development issues. Production of biochar is one of the methods permitting the reduction of the need for the disposal of animal and plant waste. Biodegradable animal waste, agricultural biomass and sewage sludge can be effectively used for the production of energy through pyrolysis. Additional benefits include a reduction in the volume of waste subjected to thermal processing, as well as the elimination of pathogenic microorganisms potentially occurring e.g., in cattle manure and sewage sludge. The use of the above waste material in the production of biochar may also lead indirectly to the reduction of methane emissions from landfills and reduce the necessity of seeking alternative methods of waste management [67].

Increased emissions of $\mathrm{CO}_{2}$ to the atmosphere in recent years have led to a significant disproportion between the natural emission and absorption of carbon. It is necessary to take action to balance carbon in the atmosphere by its capture and storage e.g., in the soil [68]. One of the solutions to this problem involves the use of biochar obtained from various types of biomass. Introduced into the soil, it enables the long-term sequestration of carbon. According to the literature, by adding biochar to soil at a rate of $13.5 \mathrm{t} \mathrm{ha}^{-1}$ it is possible to store the carbon within it for a minimum of two hundred years [69]. Furthermore, it has been shown that biochar may lead to a decrease in emissions of nitrous oxide $\left(\mathrm{N}_{2} \mathrm{O}\right)$ and methane $\left(\mathrm{CH}_{4}\right)$ from the soil, mediated by biotic and abiotic mechanisms [70].

One of the main applications of biochar is its use as a renewable fuel [71-73]. Carbonization products can be incinerated or co-incinerated in combined heat and power plants and power plants. Biochar in comparison with raw biomass contain less of significant amounts of chlorine, and volatile substances influencing the reduction of boiler efficiency and increased emission of inorganic particles. Changes in chlorine content result from the specificity of the pyrolysis process. During pyrolysis, the chlorine contained in the raw biomass is released in gaseous form and goes to the environment. These changes result from the changing structure of the material and the processes of degassing biomass. Inorganic compounds forming fine particles result in increased sludge production in fuel-burning boilers. This problem disappears in the moment of carbonization of a fuel, which is particularly important in the processes of biomass combustion. Biochar is therefore an important element in reducing this disadvantage [74]. Such fuels are an alternative to conventional fossil fuels (Table 4), as well as they offer the possibility of recovering energy from waste deposited in landfills [2]. An additional direction of wide use of biochar in the power industry is the acquisition of many energy products during its production. Additionally, obtained electricity and heat may successfully reduce the costs of the process and creation of cogeneration installations, which may become an important element in the creation of local power grids. Such small installations on the local market quickly and efficiently process e.g., waste from agricultural production, which creates independent power systems essential for the elimination of power and climate risks [33].

Table 4. The calorific value and contents of carbon, ash and volatiles in selected fuels and biochars $[2,26,75,76]$.

\begin{tabular}{ccccc}
\hline \multirow{2}{*}{ Fuel } & Calorific Value $\left(\mathbf{M J ~ k g} \mathbf{~}^{-\mathbf{1}}\right)$ & Carbon & Ash & Volatiles \\
\cline { 3 - 5 } & & \multicolumn{3}{c}{$\mathbf{\%}$} \\
\hline & Fossil fuels & & \\
\hline Natural gas & 48.0 & 75.0 & 0.0 & 100.0 \\
Lignite & 25.0 & 60.0 & 12.0 & 25.0 \\
Bituminous coal & $7.5-21.0$ & $66.0-73.0$ & $10.0-20.0$ & $40.0-60.0$ \\
\hline
\end{tabular}


Table 4. Cont.

\begin{tabular}{ccccc}
\hline \multirow{2}{*}{ Fuel } & Calorific Value $\left(\mathbf{M J ~ k g} \mathbf{~ k}^{-\mathbf{1}}\right)$ & Carbon & Ash & Volatiles \\
\cline { 3 - 5 } & & \multicolumn{3}{c}{} \\
& Biomass & \% \\
\hline Wood & 10.5 & 35.0 & 1.0 & 55.0 \\
Straw & 15.0 & 43.0 & 3.0 & 73.0 \\
Rapeseed & 15.3 & 44.7 & 7.3 & 78.7 \\
Sunflower & 15.7 & 17.2 & 8.3 & 74.5 \\
\hline & Biochar & & & \\
\hline Biochar from rapeseed & 23.4 & 72.7 & 21.8 & 13.6 \\
Biochar from sunflower & 20.5 & 63.4 & 28.9 & 13.4 \\
Biochar from oil palm (residues) & 17.1 & 53.8 & 3.1 & 81.9 \\
Biochar from cherry wood & 27.7 & 59.5 & 9.1 & 22.2 \\
\hline
\end{tabular}

Owing to their sorption properties, biochars can effectively immobilize contamination from solid, liquid and gaseous media. Of particular note is that more effective sorption properties are to be found in biochars produced at higher temperatures, since they have larger specific surface and higher microporosity. Research conducted so far shows that biochars can be used as sorbents in processes aimed at immobilizing the residues of pharmaceuticals and bacteriostatic antibiotics, e.g., sulfamethoxazole, from sewage [28,77], as well as heavy metals from aqueous solutions, municipal sewage and industrial wastewater [78-81]. It has also been reported that biochar was used for immobilizing such pesticides as carbaryl, atrazine, simazine and acetochlor from soils [82-84]. Because of their physicochemical and structural properties, carbonization products are an alternative to activated carbon and other treatment technologies applied to various substances, including sewage and wastewater [77]. Table 5 presents possible biochar applications for immobilizing various types of contaminants in soil and water.

Table 5. Possible biochar applications for immobilizing contaminants in soil and water.

\begin{tabular}{|c|c|c|c|}
\hline Contamination & $\begin{array}{c}\text { Type of Biochar } \\
\text { (Feedstock/Pyrolysis Temperature) }\end{array}$ & $\begin{array}{c}\text { Type of } \\
\text { Environment }\end{array}$ & References \\
\hline \multicolumn{4}{|l|}{ Agricultural chemicals } \\
\hline \multirow{2}{*}{ Atrazine } & Cattle manure $\left(450^{\circ} \mathrm{C}\right)$ & Soil & [85] \\
\hline & Cattle manure $\left(200^{\circ} \mathrm{C}\right)$ & Water & [86] \\
\hline Atrazine and simazine & Green waste $\left(450^{\circ} \mathrm{C}\right)$ & Water & [82] \\
\hline $\begin{array}{c}\text { Pentachlorophenol } \\
\text { Antibiotics }\end{array}$ & Bamboo $\left(600{ }^{\circ} \mathrm{C}\right)$ & Soil & [87] \\
\hline Sulfamethazine & Hardwood $\left(600^{\circ} \mathrm{C}\right)$ & Water & [88] \\
\hline Sulfamethoxazole & Bamboo $\left(450\right.$ and $\left.600{ }^{\circ} \mathrm{C}\right)$ & Water & [28] \\
\hline Tylosin & Hardwood $\left(850\right.$ and $\left.900^{\circ} \mathrm{C}\right)$ & Water & [89] \\
\hline Tetracycline & Rice husk $\left(450-500^{\circ} \mathrm{C}\right)$ & Water & [90] \\
\hline \multicolumn{4}{|l|}{ Other hydrocarbons } \\
\hline 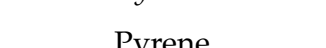 & Corncob $\left(600{ }^{\circ} \mathrm{C}\right)$ & & [91] \\
\hline & Sawdust $\left(400\right.$ i $\left.700{ }^{\circ} \mathrm{C}\right)$ & Water & [92] \\
\hline Trichloroethylene & Peanut shell (300 and $\left.700^{\circ} \mathrm{C}\right)$ & Water & [93] \\
\hline Naphthalene & Pine needles $\left(100-700{ }^{\circ} \mathrm{C}\right)$ & Water & [94] \\
\hline \multicolumn{4}{|l|}{ Heavy metals } \\
\hline Cadmium & Miscanthus sacchariflorus $\left(300-600{ }^{\circ} \mathrm{C}\right)$ & Water & [95] \\
\hline Aluminum & Rice straw $\left(100-600{ }^{\circ} \mathrm{C}\right)$ & Water & [29] \\
\hline Lead & Pine wood $\left(300^{\circ} \mathrm{C}\right)$ & Water & [96] \\
\hline
\end{tabular}

\section{Biochar as a Activated Carbons}

In recent years there has been an increase in interest in the use of active coals resulting mainly from their low production cost and favorable physicochemical properties, which include a strongly 
developed specific surface, very good ion-exchange properties and high mechanical and chemical durability. In general, any material which contains carbon in its composition in organic compounds may be used to produce active carbons. The raw materials used, activation process, and process parameters determine the physical properties and performance characteristics of the resulting carbon. Modifying these activation properties determines the porosity and pore volume distribution in the carbon. Activated carbon is defined as a carbonaceous material with a large internal surface area and highly developed porous structure resulting from the processing of raw materials under high temperature reactions. It is composed of $87-97 \%$ carbon but also contains other elements depending on the processing method used and raw material it is derived from. Activated carbon's porous structure allows it to adsorb materials from the liquid and gas phase. On an industrial scale, the precursors of active carbons include mainly fossil coals, wood, peat, and coconut shells. The literature presents information concerning the production of activated carbons by activating a variety of waste materials such as nut shells, sawdust, straw, fruit stones, straw, sewage sludge and many others [97]. These activities are of justified environmental character as they manage a significant amount of waste and their economic aspect is important as well. The studies carried out so far have highlighted the fact that activated carbons produced from waste materials can show a better sorption capacity than products made from traditional precursors. For example, carbons were prepared from combination of the waste tea and $\mathrm{K}_{2} \mathrm{CO}_{3}$ have high surface area and pore volume [98]. The production of active carbons takes place within two mechanisms, i.e., physical activation and chemical activation. Physical activation, also known as thermal activation, consists of two successive stages. The first step is the pyrolysis of the starting material, carried out at a high temperature (usually $500-1000{ }^{\circ} \mathrm{C}$ ). During the second step, the carbonization product obtained is activated by exposure to a high temperature $\left(800-1000^{\circ} \mathrm{C}\right)$ using an oxidizing agent such as water vapor, carbon monoxide (IV) or a mixture of these gases. If the above-mentioned stages of physical activation take place at the same time, then it is direct activation process. In the process of chemical activation, the precursor is subjected to high-temperature treatment in an inert gas atmosphere after prior impregnation or mixing with an activating agent. The activators used in chemical activation are mainly potassium and sodium hydroxide, sodium and potassium carbonates, zinc chloride, and phosphoric acid (V). The disadvantage of this method is its high cost caused by the necessity to use expensive activating agents and to introduce a stage aimed at removing the excess of the activating agent and the by-products. The physical and chemical properties of active carbons such as porous structure, highly developed specific surface area or sorbent capacity are strictly dependent on the substrates used, activation methods and conditions of the process. The properties of carbon sorbents can also be significantly altered by means of appropriate chemical modifications both during the manufacturing process and after the activation process. These processes consist mainly of the introduction of functional groups into the structure of the carbon material or on its surface, which significantly change its chemical character. Modification of carbon materials can be carried out using e.g., liquid oxidants, to which we include, primarily $\mathrm{HNO}_{3}, \mathrm{H}_{2} \mathrm{O}_{2}$ and $\left(\mathrm{NH}_{4}\right)_{2} \mathrm{~S}_{2} \mathrm{O}_{8}$. The surface of active carbons can also be modified with various types of organic and inorganic compounds, e.g., pyridine, compounds of platinum, of chromium, of silver, of copper, of potassium, of zinc, of sodium and of cobalt. This type of modification is aimed at obtaining materials with significantly increased and selective sorbent capacity. Table 6 presents the surface area values for physically and chemically activated carbons obtained from different materials [99-102].

Table 6. Surface area values for physically and chemically activated carbons obtained from different material.

\begin{tabular}{cccccc}
\hline \multicolumn{2}{c}{ Physically Activated Carbons } & \multicolumn{2}{c}{ Chemically Activated Carbons } \\
\hline Initial Material & Activation & Surface & Initial Material & Activation & Surface \\
Rice [103] & Agent & ${\text { Area } \mathrm{m}^{\mathrm{g}-1}}^{\mathrm{m}-1}$ & Agent & Area $^{\mathrm{m} 2 \mathrm{~g}-1}$ \\
Peanut shells [105] & Steam & 1122 & Rice [104] & KOH & 3263 \\
Cornstarch [107] & Thermal & 757 & Hazelnut shells [106] & KOH & 1700 \\
\hline
\end{tabular}


Table 6. Cont.

\begin{tabular}{|c|c|c|c|c|c|}
\hline \multicolumn{3}{|c|}{ Physically Activated Carbons } & \multicolumn{3}{|c|}{ Chemically Activated Carbons } \\
\hline $\begin{array}{l}\text { Grape pomace, } \\
\text { grape stalks [109] }\end{array}$ & Steam & $\begin{array}{l}266 \\
300\end{array}$ & Grape seeds [110] & $\mathrm{KOH}$ & 1860 \\
\hline Finish wood [111] & $\mathrm{CO}_{2}$ & 590 & $\begin{array}{l}\text { Eucalyptus wood, } \\
\text { Beech wood [112] }\end{array}$ & $\mathrm{KOH}$ & 2120,2460 \\
\hline Olive Stone [113] & $\mathrm{CO}_{2}$ & 1355 & Olives stones [114] & $\mathrm{ZnCl}_{2}$ & 1860 \\
\hline Sunflower stem [115] & $\mathrm{CO}_{2}$ & 438 & Stem of date palm [116] & $\begin{array}{c}\mathrm{KOH} \\
\mathrm{H}_{3} \mathrm{PO}_{4}\end{array}$ & $\begin{array}{c}947 \\
1100\end{array}$ \\
\hline Vine shoots [117] & $\mathrm{CO}_{2}$ & 1173 & Waste tea [98] & $\mathrm{K}_{2} \mathrm{CO}_{3}$ & 1722 \\
\hline
\end{tabular}

Activated carbons can be used in many sectors e.g., pharmaceutical, food industrial as additives or the emerging use. A series of studies demonstrated that activated biochar could be available for pharmaceuticals removal, such as acetaminophen, caffeine, atrazine, diclofenac, glyphosate, naproxen, ibuprofen and sulfamethazine [118]. Hoegberg et al. conducted a study to identify the maximum adsorption capacities of amitriptyline and paracetamol, separately and in combination, to activated charcoal [119]. The rapid adsorption tendencies of activated carbon have also extended the biochar applications to biomedical sciences. Activated carbons or activated charcoal have shown their functionalities in preventing gastrointestinal absorption of certain toxins and drugs, thereby enhancing their elimination even after systemic absorption [120]. Ozsoy and van Leeuwen in their study focused on decolorizing solutions of waste fruit candy extract dissolved in deionized water using activated carbon adsorption. The aim of this study was to use activated carbon in treatment methods for candy wastes to facilitate reuse of fruit pulp, sugar and organic acids in the process and minimize the wastes emanating from this industry [121].

Biochar-mediated adsorption of organic contaminants may be based on the principle of electrostatic interactions with polar or non-polar groups (Figure 2) [122-124].

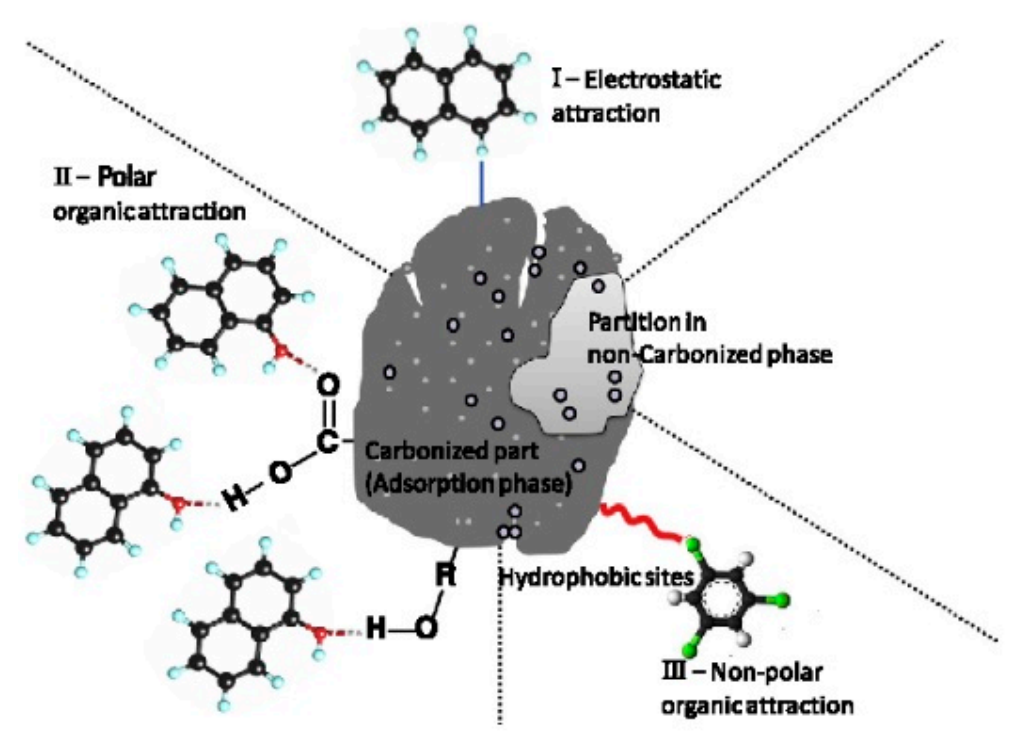

Figure 2. Mechanisms of organic substance adsorption on the surface of carbonization products [124].

Adsorption of inorganic contaminants, including ions of heavy metals, through the use of biochar is characterized by four mechanisms:

- $\quad$ ion exchange $\left(\mathrm{Na}^{+}, \mathrm{K}^{+}\right.$ions are involved),

- precipitation,

- anionic metal attraction,

- $\quad$ cationic metal attraction (Figure 3) [122,124,125]. 


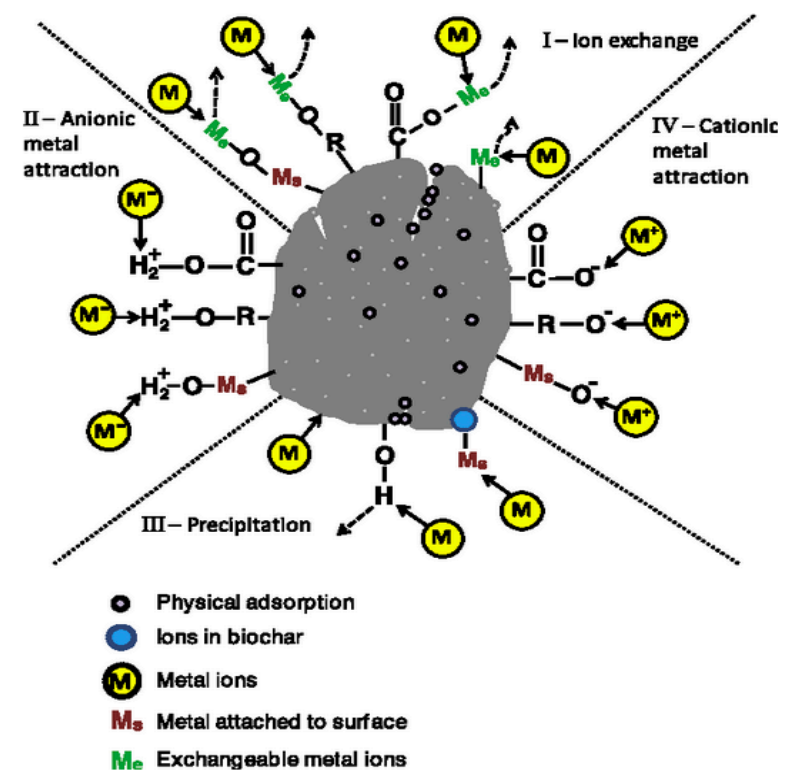

Figure 3. Types (mechanisms) of metal ion adsorption on the surface of carbonization products [124].

Mechanisms I and IV are identical normal cation exchange reactions, albeit with metal cations at I, and $\mathrm{H}^{+}$at IV.

In view of the numerous beneficial properties of biochars, in particular the high contents of organic carbon, these materials can be used to enhance the physicochemical and biological properties of soils [126].

\section{Biochar as Soil Conditioner}

Interest in biochar as a potential soil enhancer began with the discovery of preta de Indio-Indian black earth (in Amazonia), notable for its high content of carbon and nutrients [127]. As shown in previous research, the soils were created a few thousand years ago as a result of the burning of forests and natural fires, as well as soil improvement with the use of charcoal applied by pre-Columbian natives [128].

From the agricultural point of view, the application of carbonization products for soil amelioration seems to be beneficial because the treatment improves the conditions for plant growth, leading to a better yield (Figure 4, Table 7) [129]. Furthermore, due to the rapid effects and relatively low costs of such treatment, biochars are more and more frequently used in processes of soil remediation and conservation [130].

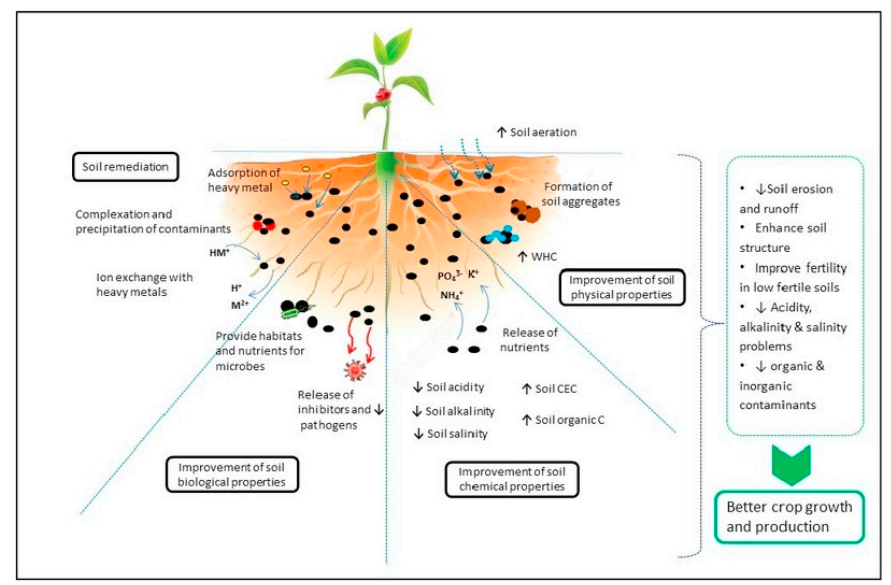

Figure 4. Influence of biochar on soil properties [131]. 
Table 7. Effect of biochar application on the yield of selected plants.

\begin{tabular}{ccccc}
\hline $\begin{array}{c}\text { Type of Biochar } \\
\text { (Feedstock) }\end{array}$ & Dose $\left(\mathbf{t ~ h a}^{\mathbf{- 1})}\right.$ & Crop & $\begin{array}{c}\text { Increase in Yield } \\
\text { Compared to the Control \% }\end{array}$ & References \\
\hline Wood & 68 & Cowpea & 20 & {$[132]$} \\
& 136.75 & Rice & 100 & 50 \\
Poultry litter & 68 & Radish & 42 & {$[39,133]$} \\
Woodchips from fruit trees & 10 & Radish & 96 & {$[134]$} \\
Cattle manure & 50.5 & Grapes & 150 & {$[135]$} \\
Hardwood & 22 & Maize & 10 & {$[136]$} \\
Wheat straw & 15 & Maize & 48 & {$[137]$} \\
\hline
\end{tabular}

The activity of biochar, after it is introduced into the soil environment, depends predominantly on the feedstocks used in its production and the parameters of the pyrolysis process. These determine the contents of macro- and micro-elements as well as harmful substances, such as e.g., heavy metals. The heterogeneous chemical composition of biochars enables their interactions with a large variety of organic and inorganic compounds present in the soil [138]. The diverse properties of biochar materials enable reactions with mineral and organic fractions of soil and the accumulation of combined mineral and organic complexes [139]. Biochars introduced to the soil are characterized by a high stability and resistance to biological decomposition, therefore they are recognized as a highly effective medium for the sequestration of carbon dioxide in soil [33]. Moreover, the application of biochars to soil leads to increased contents not only of carbon but also of other biogenic compounds, such as phosphorus, potassium, magnesium and nitrogen $[39,140]$. Owing to their large ion-exchange capacities and specific surface, biochars also produce such effects as the reduced leaching of biogenic elements from soils and a decreased emission of nitrous oxide [141]. Recent study has highlighted that crop biochar also contains biogenic silica (phytoliths) and can quickly release bioavailable silicon to enhance plant biomass and promote the biological silicon cycle in soil [142]. One of the functions of the biocarbon addition is to modify the nitrogen and phosphorus cycle. Biochar as an additive to soils has the ability to store nitrogen by increasing $\mathrm{NH}_{3}$ and $\mathrm{NH}_{4}{ }^{+}$retention, reducing $\mathrm{N}_{2} \mathrm{O}$ emissions and eluting $\mathrm{NO}_{3}$ ions, as well as inducing the development of nitrogen bacteria which directly affects the increase in soil productivity. Biochar is characterized by very different potassium contents, depending on the type of batch material used in production. Of all macronutrients present in carbonates, potassium is the best available element for plants, and the proportion of biosorptive forms is up to $95 \%$ of the total content [33]. Biochar fertilizers also lead to increased soil $\mathrm{pH}$ [143]. The related research has shown that carbonization products contain numerous alkaline substances, e.g., calcium carbonate, which may affect soil reaction, and the best effects, i.e., the highest $\mathrm{pH}$ increase, may be achieved in strongly acidified soils. Increased $\mathrm{pH}$ which is beneficial in acid tropical soils like terra preta but reduces yield in soils of high $\mathrm{pH}$ as in many temperate regions [41,144]. Biochar also impacts the physical properties of soil by improving its water retention, capacity to form aggregates, and resistance to erosion [145]. The improvement of the physical characteristics of soils resulting from the use of biochar as a soil ameliorant mainly depends on the properties of the biochar, and these are predominantly determined by the technology applied in its production $[146,147]$. Owing to their highly porous structure, carbonization products may create favorable conditions for microorganisms, as a consequence improving the fertility and productivity of soils (Table 8). For example, biochar addition to the soil with a high oil organic matter level leads to higher microbial stimulation and consequent higher $\mathrm{N}$ mineralization [148]. 
Table 8. Effects of biochar application on the soil environment of soil microorganisms.

\begin{tabular}{ccc}
\hline Type of Biochar (Feedstock) & Impact on Soil Microorganisms & References \\
\hline Willow wood and swine manure: & $\begin{array}{c}\text { Increased microbial biomass in both cases: } \\
\text { increased dehydrogenase activity }\end{array}$ & {$[149]$} \\
slow pyrolysis at $350^{\circ} \mathrm{C}$ & decreased dehydrogenase activity & \\
slow pyrolysis at $700^{\circ} \mathrm{C}$ & Increased microbial biomass & {$[150]$} \\
$\begin{array}{c}\text { Poultry litter and pine woodchips } \\
\text { (pyrolysis at } 400 \text { and } 500^{\circ} \mathrm{C} \text { ) }\end{array}$ & $\begin{array}{c}\text { Increased rate of fungal and bacterial growth } \\
\text { Leaves and fragmented branches }\end{array}$ & {$[151]$} \\
Wood (fast pyrolysis) & Increased microbial count & {$[152]$} \\
\hline
\end{tabular}

\section{Conclusions}

The research conducted so far focusing on the characteristics and possible applications of biochar in a way attempts to regulate the flow of inorganic matter in the environment and provides significant support for the conservation of the natural environment, in particular taking into account the phytoremediation and utilitarian dimension of sustainable energy management.

Owing to their physicochemical properties, biochars may be used for such purposes as carbon sequestration in soils, reduction of the bioavailability of contaminants affecting living organisms as well as water treatment. They also present significant potential for the immobilization of heavy metals from aqueous solutions and for reducing their mobility in soils. In recent years there has been an increase in interest in the use of activated carbons with elevated and selective sorption capacity. Literature describe important role the waste products as a substrate for the production of such sorbents. Pyrolysis process of biomass allows produce high quality fuel in biochar form. Such fuels are an alternative to conventional fossil fuels, as well as they offer the possibility of recovering energy from waste deposited in landfills.

According to the latest research, the application of carbonization products may effectively enhance the physicochemical properties of soils and improve the fertility of poor soils. Biochar, as a product of thermal biomass conversion carried out with a reduced availability of oxygen, is characterized by a high content of carbon and excellent sorption properties. From the point of view of agriculture, the application of biochar as a soil conditioner produces numerous benefits, such as the enhancement of the physical, chemical and biological properties of soils, and this contributes to an increased crop yield. The application of biochar in soils may be an alternative to traditional forms of mineral amendment and strengthens the ecological aspect of bioenergy engineering.

Continuous progress in research on the use of biochar, its production methods and characterization techniques allow us to conclude that biochar technologies, especially as a means of improving the quality of soil or sorbent of pollution from soil and water, will become much more important in the future. However, it should be stressed that due to the lack of specific regulations for biochar, its commercial use is limited. In order to develop the biochar industry and ensure environmental safety, uniform legal and quality regulations should be ensured.

It should, however, be emphasized that further comprehensive research is needed to investigate the feasibility of the application of biochar and to determine the optimum methods for using this highly productive material.

Funding: This research received no external funding.

Conflicts of Interest: The authors declare no conflict of interest.

\section{References}

1. IBI Biochar Standards-Standardized Product Definition and Product Testing Guidelines for Biochar That Is Used in Soil, v.2.1. Available online: http://www.biochar-international.org/sites/default/files/IBI_ Biochar_Standards_V2.1_Final.pdf (accessed on 1 February 2019).

2. Malińska, K. Legal and quality aspects of requirements defined for biochar. Inżynieria $i$ Ochrona Srodowiska 2015, 18, 359-371. 
3. Pereira, R.C.; Muetzel, S.; Arbestain, M.C.; Bishop, P.; Hina, K.; Hedley, M. Assessment of the influence of biochar on rumen and silage fermentation: A laboratory-scale experiment. Anim. Feed Sci. Technol. 2014, 196, 22-31. [CrossRef]

4. Tang, J.; Zhy, W.; Kookana, R.; Katayama, A. Characteristics of biochar and its application in remediation of contaminated soil. J. Biosci. Bioeng. 2013, 116, 653-659. [CrossRef] [PubMed]

5. Mohan, D.; Sarswat, A.; Ok, S.Y.; Pittman, C.U., Jr. Organic and inorganic contaminants removal from water with biochar, a renewable, low cost and sustainable adsorbent-A critical review. Bioresour. Technol. 2014, 160, 191-202. [CrossRef]

6. Steiner, C.; Das, K.C.; Melear, N.; Lakly, D. Reducing nitrogen loss during poultry litter composting using biochar. J. Environ. Qual. 2010, 39, 1236-1242. [CrossRef]

7. Steiner, C.; Melear, N.; Harris, K.; Das, K.C. Biochar as bulking agent for poultry litter composting. Carbon Manag. 2011, 2, 227-230. [CrossRef]

8. Malińska, K.; Zabochnicka-Świątek, M.; Dach, J. Effects of biochar amendment on ammonia emission during composting of sewage sludge. Ecol. Eng. 2014, 71, 474-478. [CrossRef]

9. Malińska, K.; Dach, J. Biochar as a supplementary material for biogas production. Ecol. Eng. 2015, 4, 117-124. [CrossRef]

10. Paethanom, A.; Bartocci, P.; D’ Alessandro, B.; D’ Amico, M.; Testarmata, F.; Moriconi, N.; Slopiecka, K.; Yoshikawa, K.; Fantozzi, F. A low-cost pyrogas cleaning system for power generation: Scaling up from lab to pilot. Appl. Energy 2013, 111, 1080-1088. [CrossRef]

11. Bartocci, P.; Bidini, G.; Saputo, P.; Fantozzi, F. Biochar pellet carbon footprint. Chem. Eng. Trans. 2016, 50, 217-222.

12. Bartocci, P.; Zampilli, M.; Bidini, G.; Fantozzi, F. Hydrogen-rich gas production through steam gasification of charcoal pellet. Appl. Therm. Eng. 2018, 132, 817-823. [CrossRef]

13. Saxena, R.C.; Seal, D.; Kumar, S.; Goyal, H.B. Thermo-chemical routes for hydrogen rich gas from biomass: a review. Renew. Sustain. Energy Rev. 2008, 12, 1909-1927. [CrossRef]

14. Piskowska-Wasiak, J. Cleaning and conditioning of gas from biomass gasification for production of SNG (Substitute Natural Gas). Nafta-Gaz 2011, 67, 347-360.

15. Wróblewski, R. The concept of a small cogeneration system integrated with biomass gasification. Energy Policy J. 2014, 17, 159-170.

16. Chen, W.; Kuo, P. A study on torrefaction of various biomass materials and its impact on lignocellulosic structure simulated by a thermogravimetry. Energy 2010, 35, 2580-2586. [CrossRef]

17. Kopczński, M.; Zuwała, J. Biomass torrefaction as a way for elimination of technical barriers existing in large-scale co-combustion. Energy Policy J. 2013, 16, 271-284.

18. Piaskowska-Silarska, M. Analysis of the possibility of obtaining energy from biomass in Poland. Energy Policy J. 2014, 17, 239-248.

19. Uddin, M.N.; Techato, K.; Taweekun, J.; Rahman, M.M.; Rasul, M.G.; Mahlia, T.M.I.; Ashrafur, S.M. An Overview of Recent Developments in Biomass Pyrolysis Technologies. Energies 2018, 11, 3115. [CrossRef]

20. Lewandowski, W.M.; Radziemska, E.; Ryms, M.; Ostrowski, P. Modern methods of thermochemical biomass conversion into gas, liquid and solid fuels. Ecol. Chem. Eng. S 2011, 18, 39-47.

21. Malińska, K. Biochar-A response to current environmental issues. Eng. Prot. Environ. 2012, 15, 387-403.

22. Montoya, J.I.; Chejne-Janna, F.; Garcia-Pérez, M. Fast pyrolysis of biomass: A review of relevant aspects. Part I: Parametric study. Dyna 2015, 82, 239-248. [CrossRef]

23. Park, J.; Hung, I.; Gan, Z.; Rojas, O.J.; Lim, K.H.; Park, S. Activated carbon from biochar: influence of its physicochemical properties on the sorption characteristics of phenanthrene. Bioresour. Technol. 2013, 149, 383-389. [CrossRef] [PubMed]

24. Uchimiya, M.; Wartelle, L.H.; Klasson, K.T.; Fortier, C.A.; Lima, I.M. Influence of pyrolysis temperature on biochar property and function as a heavy metal sorbent in soil. J. Agric. Food Chem. 2011, 59, 2501-2510. [CrossRef] [PubMed]

25. Kwapinski, W.; Byrne, C.M.P.; Kryachko, E.; Wolfram, P.; Adley, C.; Leahy, J.J.; Novotny, E.H.; Hayes, M.H.B. Biochar from Biomass and Waste. Waste Biomass Valor. 2010, 1, 177-189. [CrossRef]

26. Sànchez, M.E.; Lindao, E.; Margaleff, D.; Martínez, O.; Morán, A. Pyrolysis of agricultural residues from rape and sunflower: Production and characterization of biofuels and biochar soil management. J. Anal. Appl. Pyrolysis 2009, 85, 142-144. [CrossRef] 
27. Shen, Y.S.; Wang, S.L.; Tzou, Y.M.; Yan, Y.Y.; Kuan, W.H. Removal of hexavalent Cr by coconut coir and derived chars-the effect of surface functionality. Bioresour. Technol. 2012, 104, 165-172. [CrossRef] [PubMed]

28. Yao, Y.; Gao, B.; Chen, H.; Jiang, L.; Inyang, M.; Zimmerman, A.R.; Cao, X.; Yang, L.; Xue, Y.; Li, H. Adsorption of sulfamethoxazole on biochar and its impact on reclaimed water irrigation. J. Hazard. Mater. 2012, 209, 408-413. [CrossRef]

29. Qian, L.; Chen, B. Dual role of biochars as adsorbents for aluminum: The effects of oxygen-containing organic components and the scattering of silicate particles. Environ. Sci. Technol. 2013, 47, 8759-8768. [CrossRef]

30. Xu, X.; Cao, X.; Zhao, L. Comparison of rice husk-and dairy manure-derived biochars for simultaneously removing heavy metals from aqueous solutions: Role of mineral components in biochars. Chemosphere 2013, 92, 955-961. [CrossRef]

31. Song, W.; Guo, M. Quality variations of poultry litter biochar generated at different pyro lysis temperatures. J. Anal. Appl. Pyrolysis 2012, 94, 138-145. [CrossRef]

32. Ibarrola, R.; Shackely, S.; Hammond, J. Pyrolysis biochar systems for recovering biodegradable materials: A life cycle carbon assessment. Waste Manag. 2012, 32, 859-868. [CrossRef] [PubMed]

33. Lehmann, J.; Rilling, M.C.; Thies, J.; Masiello, C.A.; Hockaday, W.C.; Crowley, D. Biochar effects on soil biota-A review. Soil Biol. Biochem. 2011, 43, 1812-1836. [CrossRef]

34. Atkinson, C.J.; Fitzgerald, J.D.; Hipps, N.A. Potential mechanisms for achieving agricultural benefits from biochar application to temperate soils: Review. Plant Soil 2010, 337, 1-18. [CrossRef]

35. Burrell, L.D.; Zehetner, F.; Rampazzo, N.; Wimmer, B.; Soja, G. Long-term effects of biochar on soil physical properties. Geoderma 2016, 282, 96-102. [CrossRef]

36. Yamato, M.; Okimori, Y.; Wibowo, I.F.; Anshori, S.; Ogawa, M. Effects of the application of charred bark in Acacia mangium on the yield of maize, cowpea, peanut and soil chemical properties in south Sumatra, Indonesia. Soil Sci. Plant Nutr. 2006, 52, 489-495. [CrossRef]

37. Tsai, W.T.; Lee, M.K.; Chang, Y.M. Fast pyrolysis of rice straw, sugarcane bagasse and coconut shell in an induction-heating reactor. J. Anal. Appl. Pyrolysis 2006, 76, 230-237. [CrossRef]

38. Nguyen, B.T.; Lehmann, J. Black carbon decomposition under varying water regimes. Org. Geochem. 2009, 40, 846-853. [CrossRef]

39. Chan, K.Y.; Van Zwieten, L.; Meszaros, I.; Downie, A.; Joseph, S. Agronomic values of green waste biochar as a soil amendment. Aust. J. Soil Res. 2007, 45, 629-634. [CrossRef]

40. Magrini-Bair, K.A.; Czernik, S.; Pilath, H.M.; Evans, R.J.; Maness, P.C.; Leventhal, J. Biomass derived, carbon sequestration, designed fertilizers. Ann. Environ. Sci. 2009, 3, 217-225.

41. Novak, J.M.; Busscher, W.J.; Laird, D.L.; Ahmedna, M.; Watts, D.W.; Niandou, M.A.S. Impact of biochar amendment on fertility of a Southeastern coastal plain soil. Soil Sci. 2009, 174, 105-112. [CrossRef]

42. Busscher, W.J.; Novak, J.M.; Evans, D.E.; Watts, D.W.; Niandou, M.A.S.; Ahmedna, M. Influence of pecan biochar on physical properties of Norfolk loamy sand. Soil Sci. 2010, 175, 10-44. [CrossRef]

43. Bridle, T.R.; Pritchard, D. Energy and nutrient recovery from sewage sludge via pyrolysis. Water Sci. Technol. 2004, 50, 169-175. [CrossRef] [PubMed]

44. Rondon, M.A.; Lehmann, J.; Ramirez, J.; Hurtado, M. Biological nitrogen fixation by common beans (Phaseolus vulgaris L) increases with bio-char additions. Biol. Fertil. Soils 2007, 43, 699-708. [CrossRef]

45. Popp, J.; Lakner, Z.; Harangi-Rákos, M.; Fári, M. The effect of bioenergy expansion: Food, energy, and environment. Renew. Sustain. Energy Rev. 2014, 32, 559-578. [CrossRef]

46. Lédé, J. Biomass pyrolysis: Comments on some sources of confusions in the definitions of temperatures and heating rates. Energies 2010, 3, 886-898. [CrossRef]

47. Onay, O. Influence of pyrolysis temperature and heating rate on the production of bio-oil and char from safflower seed by pyrolysis, using a well-swept fixed-bed reactor. Fuel Process. Technol. 2007, 88, 523-531. [CrossRef]

48. Sinha, S.; Jhalani, A.; Ravi, M.R.; Ray, A. Modelling of Pyrolysis in Wood: A Review. Sol. Energy Soc. India J. 2000, 10, 41-62.

49. Jahirul, M.I.; Rasul, M.G.; Chowdhury, A.A.; Ashwath, N. Biofuels Production through Biomass Pyrolysis-A Technological Review. Energies 2012, 5, 4952-5001. [CrossRef]

50. Van den Bergh, C. Biochar and waste law: A comparative analysis. Eur. Energy Environ. Law Rev. 2009, $18,243-253$. 
51. Montanarella, L.; Lugato, E. The application of biochar in the EU: Challenges and opportunities. Agron. J. 2013, 3, 462-473. [CrossRef]

52. Vereš, J.; Koloničný, J.; Ochodek, T. Biochar status under international law and regulatory issues for the practical application. Chem. Eng. Trans. 2014, 37, 799-804.

53. Van Laer, T.; De Smedt, P.; Ronsse, F.; Ruysschaert, G.; Boeckx, P.; Verstraete, W.; Buysse, J.; Lavrysen, L.J. Legal constraints and opportunities for biochar: A case analysis of EU law. GCB Bioenergy 2015, 7, 14-24. [CrossRef]

54. Directive 2008/98/EC of the European Parliament and of the Council of 19 November 2008 on Waste and Repealing Certain Directives. Available online: http:/ /www.lex.pl/serial-akt/- /akt/dz-u-ue-1-2008-312-3 (accessed on 1 February 2019).

55. Directive 2001/77/EC of the European Parliament and of the Council of 27 September 2001. Available online: http:/ / orka.sejm.gov.pl/Drektywy.nsf/all/32001L0077/\%24File/32001L0077.pdf (accessed on 1 February 2019).

56. Ustawa z dnia 14 Grudnia 2012 o Odpadach [Waste Act of 14 December 2012]. Available online: http: / /isap.sejm.gov.pl/DetailsServlet?id=WDU20130000021 (accessed on 1 February 2019).

57. Regulation (EC) No 1907/2006 of the European Parliament and of the Council of 18 December 2006 Concerning the Registration, Evaluation, Authorisation and Restriction of Chemicals (REACH). Available online: http: / / eurlex.europa.eu/LexUriServ/LexUriServ.do?uri=OJ:L:2009:036:0084:0084:PL:PDF (accessed on 1 February 2019).

58. Regulation (EC) No 2003/2003 of the European Parliament and of the Council of 13 October 2003 Relating to Fertilisers. Available online: https:/ / eur-lex.europa.eu/legal-content/EN/TXT/?uri=CELEX\% 3A32003R2003PDF (accessed on 1 February 2019).

59. EBC. European Biochar Certificate-Guidelines for Sustainable Production of Biochar; Version 6.2E; European Biochar Foundation (EBC): Arbraz, Switzerland, 2012.

60. Biochar Quality Mandate (BQM) v.1.0. Available online: http://www.britishbiocharfoundation.org/wpcontent/uploads /BQM-V1.0.pdf (accessed on 1 February 2019).

61. Malińska, K.; Mełgieś, K. Current quality and legal requirements for biochar as a fertilizers and soil improver. Prace Inst. Ceram. Mater. Bud. 2016, 9, 82-95.

62. Refertil Biochar EU Policy-Support Abstract Draft 2014. D 2.3. Biochar Policy Supporting Report, Concerning the Absence of Potential Risks for the Different Environmental Compartments, for the Plants and for Human Health through the Food Chain Resulting from the Use of These Materials in Agricultural Soils. Available online: http://www.refertil.info/sites / default/ files/REFERTIL_289785_BIOCHAR_POLICY_ abstract_draft_2014.pdf (accessed on 1 February 2019).

63. Hibler, I.; Blum, F.; Leifeld, J.; Schmidt, H.P.; Bucheli, T.D. Quantitative determination of PAHs in biochar: A prerequisite to ensure its quality and safe application. J. Agric. Food Chem. 2012, 60, 3042-3050.

64. Fabbri, D.; Rombolà, A.G.; Torri, C.; Spokas, K.A. Determination of polycyclic aromatic carbons in biochar and biochar amended soil. J. Anal. Appl. Pyrolysis 2013, 103, 60-67. [CrossRef]

65. Quilliam, R.S.; Rangecroft, S.; Emmett, B.A.; Deluca, T.H.; Jones, D.L. Is biochar a source or sink for polycyclic aromatic hydrocarbons (PAH) compounds in agricultural soils? GCB Bioenergy 2013, 5, 96-103. [CrossRef]

66. Regulation of the Minister of Agriculture and Rural Development, of 18 June 2008, on Implementation of Certain Provisions of the Act on Fertilizers and Fertilization. Available online: http://isap.sejm.gov.pl/ DetailsServlet?id=WDU2008119 (accessed on 1 February 2019).

67. Singh, B.P.; Cowie, A.L.; Smernik, R.J. Biochar carbon stability in a clayey soil as a function of feedstock and pyrolysis temperature. Environ. Sci. Technol. 2012, 46, 11770-11778. [CrossRef]

68. Bis, Z. Biochar - return to the past, opportunity for the future. Available online: https://www.cire.pl/pliki/ 2/biowegiel.pdf (accessed on 1 February 2019).

69. Matovic, D. Biochar as a viable carbon sequestration option: Global and Canadian perspective. Energy 2011, 36, 2011-2016. [CrossRef]

70. Verheijen, F.; Jeffery, S.; Bastos, A.C.; Van der Velde, M.; Diafas, I. Biochar Application to Soils-A Critical Scientific Review of Effects on Soil Properties, Processes and Functions; European Commission: Ispra, Italy, 2010.

71. Skreiberg, Ø.; Wang, L.; Khalil, R.; Gjølsjø, S.; Turn, S. Enabling the biocarbon value chains for energy and metallurgical industries. In Proceedings of the European Biomass Conference and Exhibition, Copenhagen, Denmark, 14-18 May 2018; pp. 1221-1228. 
72. Olszewski, M.; Kempegowda, R.S.; Skreiberg, Ø.; Wang, L.; Løvås, T. Techno-Economics of Biocarbon Production Processes under Norwegian Conditions. Energy Fuels 2017, 31, 14338-14356. [CrossRef]

73. Bach, Q.V.; Tran, K.Q.; Skreiberg, Ø. Comparative study on the thermal degradation of dry- and wet-torrefied woods. Appl. Energy 2017, 185, 1051-1058. [CrossRef]

74. McLaren, D.A. Comparative global assessment of potential negative emissions technologies. Process Saf. Environ. Prot. 2012, 90, 489-500. [CrossRef]

75. Sukiran, M.A.; Kheang, L.S.; Baker, N.A.; May, C.Y. Production and characterization of biochar from the pyrolysis of empty fruit bunches. Am. J. Appl. Sci. 2011, 8, 984-988. [CrossRef]

76. Gheorghe, C.; Marculescu, C.; Badea, A.; Dinca, C.; Apostol, T. Effect of pyrolysis conditions on bio-char production from biomass. Conference papers of 3rd WSEAS International Conference on Renewable Energy Sources. 2009. Available online: https:/ / pdfs.semanticscholar.org/c47b/51964c1fc9ba5ca1bdb660b5fe31478532f4. pdf (accessed on 1 February 2019).

77. Sun, K.; Ro, K.; Guo, M.; Novak, J.; Mashayekhi, H.; Xing, B. Sorption of bisphenol A, $17 \alpha$-ethinyl estradiol and phenanthrene on thermally and hydrothermally produced biochars. Bioresour. Technol. 2011, 102, 5757-5763. [CrossRef] [PubMed]

78. Tong, X.; Li, J.; Yuan, J.; Xu, R. Adsorption of $\mathrm{Cu}(\mathrm{II})$ by biochars generated from three crop straws. J. Chem. Eng. 2011, 172, 828-834. [CrossRef]

79. Regmi, P.; Moscoso, J.L.G.; Kumar, S.; Cao, X.; Mao, J.; Scharfan, G. Removal of copper and cadmium from aqueous solutions using switchgrass biochar produced via hydrothermal carbonization proces. J. Environ. Manag. 2012, 109, 61-69. [CrossRef] [PubMed]

80. Inyang, M.; Gao, B.; Yao, Y.; Xue, Y.; Zimmerman, A.R.; Pullammanappallil, P.; Cao, X. Removal of heavy metals from aqueous solution by biochars derived from anaerobically digested biomass. Bioresour. Technol. 2012, 110, 50-56. [CrossRef] [PubMed]

81. Mohan, D.; Rajput, S.; Singh, V.K.; Steele, P.H.; Pittman, C.U. Modelling and evaluation of chromium remediation from water using low cost bio-char, a green adsorbent. J. Hazard. Mater. 2011, 188, 319-333. [CrossRef] [PubMed]

82. Zheng, W.; Guo, M.; Chow, T.; Bennet, D.N.; Rajagopalan, N. Sorption properties of greenwaste biochar for two triazine pesticides. J. Hazard. Mater. 2010, 181, 121-126. [CrossRef]

83. Zhang, P.; Sun, H.; Yu, L.; Sun, T. Adsorption and catalytic hydrolysis of carbaryl and antrazine on pig manure-derived biochars: impact of structural properties of biochars. J. Hazard. Mater. 2013, 244, 217-224. [CrossRef]

84. Spokas, K.A.; Koskinen, W.C.; Baker, J.M.; Reicosky, D.C. Impacts of woodchip biochar additions on greenhouse gas production and sorption/degradation of two herbicides in a Minnesota soil. Chemosphere 2009, 77, 574-581. [CrossRef]

85. Cao, X.; Ma, L.; Liang, Y.; Gao, B.; Harris, W. Simultaneous immobilization of lead and atrazine in contaminated soils using dairy-manure biochar. Environ. Sci. Technol. 2011, 45, 4884-4889. [CrossRef] [PubMed]

86. Cao, X.; Harris, W. Properties of dairy-manure-derived biochar pertinent to its potential use in remediation. Bioresour. Technol. 2010, 101, 5222-5228. [CrossRef] [PubMed]

87. Xu, T.; Lou, L.; Luo, L.; Cao, R.; Duan, D.; Chen, Y. Effect of bamboo biochar on pentachlorophenol leachability and bioavailability in agricultural soil. Sci. Total. Environ. 2012, 414, 727-731. [CrossRef] [PubMed]

88. Teixido, M.; Pignatello, J.J.; Beltran, J.L.; Granados, M.; Peccia, J. Speciation of the ionizable antibiotic sulfamethazine on black carbon (biochar). Environ. Sci. Technol. 2011, 45, 10020-10027. [CrossRef] [PubMed]

89. Jeong, C.Y.; Wang, J.J.; Dodla, S.K.; Eberhardt, T.L.; Groom, L. Effect of biochar amendment on tylosin adsorption-desorption and transport in two different soils. J. Environ. Qual. 2012, 41, 1185-1192. [CrossRef] [PubMed]

90. Liu, P.; Liu, W.J.; Jiang, H.; Chen, J.J.; Li, W.W.; Yu, H.Q. Modification of biochar derived from fast pyrolysis of biomass and its application in removal of tetracycline from aqueous solution. Bioresour. Technol. 2012, 121, 235-240. [CrossRef] [PubMed]

91. Hale, S.E.; Hanley, K.; Lehmann, J.; Zimmerman, A.R.; Cornelissen, G. Effects of chemical, biological, and physical aging as well as soil addition on the sorption of pyrene to activated carbon and biochar. Environ. Sci. Technol. 2011, 45, 10445-10453. [CrossRef] 
92. Zhang, W.; Wang, L.; Sun, H. Modifications of black carbons and their influence on pyrene sorption. Chemosphere 2011, 85, 1306-1311. [CrossRef]

93. Ahmad, M.; Lee, S.S.; Dou, X.; Mohan, D.; Sung, J.K.; Yang, J.E.; Ok, Y.S. Effects of pyrolysis temperature on soybean stover-and peanut shell-derived biochar properties and TCE adsorption in water. Bioresour. Technol. 2012, 118, 536-544. [CrossRef]

94. Chen, B.; Zhou, D.; Zhu, L. Transitional adsorption and partition on nonpolar and polar aromatic contaminants by biochars of pine needles with different pyrolytic temperatures. Environ. Sci. Technol. 2008, 42, 5137-5143. [CrossRef]

95. Kim, W.K.; Shim, T.; Kim, Y.S.; Hyun, S.; Ryu, C.; Park, Y.K.; Jung, J. Characterization of cadmium removal from aqueous solution by biochar produced from a giant Miscanthus at different pyrolytic temperatures. Bioresour. Technol. 2013, 138, 266-270. [CrossRef] [PubMed]

96. Liu, Z.; Zhang, F.S. Removal of lead from water using biochars prepared from hydrothermal liquefaction of biomass. J. Hazard. Mater. 2009, 167, 933-939. [CrossRef]

97. Purnomo, C.W.; Castello, D.; Fiori, L. Granular Activated Carbon from Grape Seeds Hydrothermal Char. Appl. Sci. 2018, 8, 331. [CrossRef]

98. Gurten, I.I.; Ozmak, M.; Yagmur, E.; Aktas, Z. Preparation and characterisation of activated carbon from waste tea using $\mathrm{K}_{2} \mathrm{CO}_{3}$. Biomass Bioenergy 2012, 37, 73-81. [CrossRef]

99. Tamer, M.A.; Ismail, A.; Mohd, A.A.; Ahmad, A.F. Review: Production of activated carbon from agricultural byproducts via conventional and microwave heating. J. Chem. Technol. Biotechnol. 2013, 88, 1183-1190.

100. Bedia, J.; Peñas-Garzón, M.; Gómez-Avilés, A.; Rodriguez, J.J.; Belver, C. A Review on the Synthesis and Characterization of Biomass-Derived Carbons for Adsorption of Emerging Contaminants from Water. J. Carbon Res. 2018, 4, 63. [CrossRef]

101. Hagemann, N.; Spokas, K.; Schmidt, H.-P.; Kägi, R.; Böhler, M.A.; Bucheli, T.D. Activated Carbon, Biochar and Charcoal: Linkages and Synergies across Pyrogenic Carbon's ABCs. Water 2018, 10, 182. [CrossRef]

102. González-García, P. Activated carbon from lignocellulosics precursors: A review of the synthesis methods, characterization techniques and applications. Renew. Sustain. Energy Rev. 2018, 82, 1393-1414. [CrossRef]

103. Amaya, A.; Medero, N.; Tancredi, N.; Silva, H.; Deiana, C. Activated carbon briquettes from biomass materials. Bioresour. Technol. 2007, 98, 1635-1641. [CrossRef]

104. Liu, D.; Zhang, W.; Lin, H.; Li, Y.; Lu, H.; Wang, Y. A green technology for the preparation of high capacitance rice husk-based activated carbon. J. Clean. Prod. 2015, 1-9. [CrossRef]

105. Wilson, K.; Yang, H.; Seo, C.W.; Marshall, W.E. Select metal adsorption by activated carbon made from peanut shells. Bioresour. Technol. 2006, 97, 2266-2270. [CrossRef]

106. Unur, E. Functional nanoporous carbons from hydrothermally treated biomass for environmental purification. Microporous Mesoporous Mater. 2013, 168, 92-101. [CrossRef]

107. Lei, H.; Wang, Y.; Huo, J. Porous graphitic carbon materials prepared from cornstarch with the assistance of microwave irradiation. Microporous Mesoporous Mater. 2015, 210, 39-45. [CrossRef]

108. Wang, D.; Geng, Z.; Li, B.; Zhang, C. High performance electrode materials for electric double-layer capacitors based on biomass-derived activated carbons. Electrochim. Acta 2015, 173, 377-384. [CrossRef]

109. Sardella, F.; Gimenez, M.; Navas, C.; Morandi, C.; Deiana, C.; Sapag, K. Conversion of viticultural industry wastes into activated carbons for removal of lead and cadmium. J. Environ. Chem. Eng. 2014, 3, 253-260. [CrossRef]

110. Ruiz, B.; Ruisánchez, E.; Gil, R.R.; Ferrera-Lorenzo, N.; Lozano, M.S.; Fuente, E. Sustainable porous carbons from lignocellulosic wastes obtained from the extraction of tannins. Microporous Mesoporous Mater. 2015, 209, 23-29. [CrossRef]

111. Kilpimaa, S.; Runtti, H.; Kangas, T.; Lassi, U.; Kuokkanen, T. Physical activation of carbon residue from biomass gasification: Novel sorbent for the removal of phosphates and nitrates from aqueous solution. J. Ind. Eng. Chem. 2014, 21, 1354-1364. [CrossRef]

112. Marco-Lozar, J.P.; Linares-Solano, A.; Cazorla-Amorós, D. Effect of the porous texture and surface chemistry of activated carbons on the adsorption of a germanium complex from dilute aqueous solutions. Carbon 2011, 49, 3325-3331. [CrossRef]

113. Tsyntsarski, B.; Stoycheva, I.; Tsoncheva, T.; Genova, I.; Dimitrov, M.; Petrova, B.; Paneva, D.; Zheleva, Z.; Budinova, T.; Kolev, H.; et al. Activated carbons from waste biomass and low rank coals as catalyst supports for hydrogen production by methanol decomposition. Fuel Process. Technol. 2015, 137, 139-147. [CrossRef] 
114. Temdrara, L.; Khelifi, A.; Addoun, A.; Spahis, N. Study of the adsorption properties of lignocellulosic material activated chemically by gas adsorption and immersion calorimetry. Desalination 2008, 223, 274-282. [CrossRef]

115. Román, S.; Valente-Nabais, J.M.; Ledesma, B.; González, J.F.; Laginhas, C.; Titirici, M.M. Production of low-cost adsorbents with tunable surface chemistry by conjunction of hydrothermal carbonization and activation processes. Microporous Mesoporous Mater. 2013, 165, 127-133.

116. Jibril, B.; Houache, O.; Al-Maamari, R.; Al-Rashidi, B. Effects of $\mathrm{H}_{3} \mathrm{PO}_{4}$ and $\mathrm{KOH}$ in carbonization of lignocellulosic material. J. Anal. Appl. Pyrolysis 2008, 83, 151-156. [CrossRef]

117. Nabais, J.M.V.; Laginhas, C.; Carrott, P.J.M.; Carrott, M.M.L.R. Thermal conversion of a novel biomass agricultural residue (vine shoots) into activated carbon using activation with $\mathrm{CO}_{2}$. J. Anal. Appl. Pyrolysis 2010, 87, 8-13. [CrossRef]

118. Tan, X.-F.; Liu, S.-B.; Liu, Y.-G.; Gu, Y.-L.; Zeng, G.-M.; Hu, X.-J.; Wang, X.; Liu, S.-H.; Jiang, L.-H. Biochar as potential sustainable precursors for activated carbon production: Multiple applications in environmental protection and energy storage. Bioresour. Technol. 2017, 227, 359-372. [CrossRef] [PubMed]

119. Hoegberg, L.C.; Groenlykke, T.B.; Abildtrup, U.; Angelo, H.R. Combined paracetamol and amitriptyline adsorption to activated charcoal. Clin. Toxicol. 2010, 48, 898-903. [CrossRef] [PubMed]

120. Nanda, S.; Dalai, A.K.; Berruti, F.; Kozinski, J.A. Biochar as an experimental bioresource for energy, agronomy, carbon sequestration, activated carbon and specialty materials. Waste Biomass Valor. 2016, 7, 201-235. [CrossRef]

121. Ozsoy, H.D.; van Leeuwen, J. Removal of color from fruit candy waste by activated carbon adsorption. J. Food Eng. 2010, 101, 106-112. [CrossRef]

122. Bogusz, A.; Cejner, M. Biochar materials in adsorption of organic and inorganic contaminants. Inżynieria środowiska 2016, 22, 9-33.

123. Sun, K.; Jin, J.; Keiluweit, M.; Kleber, M.; Wang, Z.; Pan, Z.; Xing, B. Polar and aliphatic domains regulate sorption of phthalic acid esters (PAEs) to biochars. Bioresour. Technol. 2012, 118, 120-127. [CrossRef]

124. Ahmad, M.; Rajapaksha, A.U.; Lim, J.E.; Zhang, M.; Bolan, N.; Mohan, D.; Vithanage, M.; Lee, S.S.; Ok, Y.S. Biochar as a sorbent for contaminant management in soil and water: A review. Chemosphere 2014, 99, 19-33. [CrossRef]

125. Tan, X.; Liu, Y.; Zeng, G.; Wang, X.; Hu, X.; Gu, Y.; Yang, Z. Application of biochar for the removal of pollutants from aqueous solutions. Chemosphere 2015, 125, 70-85. [CrossRef]

126. Enders, A.; Hanley, K.; Whitman, T.; Joseph, S.; Lehmann, J. Characterization of biochars to evaluate recalcitrance and agronomic performance. Bioresour. Technol. 2012, 114, 644-653. [CrossRef]

127. Bezerra, J.; Turnhout, E.; Vasquez, I.M.; Rittl, T.F.; Arts, B.; Kuyper, T.W. The promises of the Amazonian soil: Shifts in discourses of Terra Preta and biochar. J. Environ. Policy Plan. 2016, 46, 1-13. [CrossRef]

128. Medyńska-Juraszek, A. Biochar as a soil amendment. Soil Sci. Annual. 2016, 67, 151-157. [CrossRef]

129. Macdonald, L.; Farrell, M.; Van Zwieten, L.; Krull, E. Plant growth responses to biochar addition: An Australian soils perspective. Biol. Fertil. Soils 2014, 50, 1035-1045. [CrossRef]

130. Beesley, L.; Moreno-Jiménez, E.; Gomez-Eyles, J.; Harris, E.; Robinson, B.; Sizmur, T. A review of biochars' potential role in the remediation, revegetation and restoration of contaminated soils. Environ. Pollut. 2011, 159, 3269-3282. [CrossRef]

131. Palansooriya, K.N.; Ok, Y.S.; Awad, Y.M.; Lee, S.S.; Sung, J.K.; Koutsospyros, A.; Moon, D.H. Impacts of biochar application on upland agriculture: A review. J. Environ. Manag. 2019, 234, 52-64. [CrossRef]

132. Glaser, B.; Lehmann, J.; Zech, W. Ameliorating physical and chemical properties of highly weathered soils in the tropics with charcoal-a review. Biol Fertil. Soils 2002, 35, 1719-1730. [CrossRef]

133. Chan, K.Y.; Van Zwieten, L.; Meszaros, I.; Downie, A.; Joseph, S. Using poultry litter biochars as soil amendments. Aust. J. Soil Res. 2008, 46, 437-444. [CrossRef]

134. Genesio, L.; Miglietta, F.; Baronti, S.; Vaccari, F.P. Biochar increases vineyard productivity without affecting grape quality: Results from a four years field experiment in Tuscany. Agric. Ecosyst. Environ. 2015, 201, $20-25$. [CrossRef]

135. Uzoma, K.C.; Inoue, M.; Andry, H.; Fujimaki, H.; Zahoor, A.; Nishihara, E. Effect of cow manure biochar on maize productivity under sandy soil condition. Soil Use Manag. 2011, 27, 205-212. [CrossRef]

136. Rogovska, N.; Laird, D.A.; Rathke, S.J.; Karlen, D.L. Biochar impact on Midwestern Mollisols and maize nutrient availability. Geoderma 2014, 230, 340-347. [CrossRef] 
137. Liu, Z.; Chen, X.; Jing, Y.; Li, Q.; Zhang, J.; Huang, Q. Effects of biochar amendment on rapeseed and sweet potato yields and water stable aggregate in upland red soil. Catena 2014, 123, 45-51. [CrossRef]

138. Cross, A.; Sohi, S. The priming potential of biochar products in relation to labile carbon contents and soil organic matter status. Soil Biol. Biochem. 2011, 43, 2127-2134. [CrossRef]

139. Zhang, Q.; Du, Z.; Lou, Y.; He, X. A one-year short-term biochar application improved carbon accumulation in large macro aggregate fractions. Catena 2015, 127, 26-31. [CrossRef]

140. Laird, D.A. The charcoal vision: A win-win-win scenario for simultaneously producing bioenergy, permanently sequestering carbon, while improving soil and water quality. Agron. J. 2008, 100, 178-181. [CrossRef]

141. Woolf, D.; Amonette, J.E.; Street-Perrott, F.A.; Lehmann, J.; Joseph, S. Sustainable biochar to mitigate global climate change. Nat. Commun. 2010, 1, 56. [CrossRef]

142. Li, Z.; Delvaux, B.; Yans, J.; Dufour, N.; Houben, D.; Cornelis, J.T. Phytolith-rich biochar increases cotton biomass and silicon-mineralomass in a highly weathered soil. J. Plant Nutr. Soil Sci. 2018, 181, 537-546. [CrossRef]

143. Yuan, J.; Xu, R.; Zhang, H. The forms of alkalis in the biochar produced from crop residues at different temperatures. Bioresour. Technol. 2011, 102, 3488-3497. [CrossRef]

144. Zong, Y.; Xiao, Q.; Lu, S. Acidity, water retention, and mechanical physical quality of a strongly acidic Ultisol amended with biochars derived from different feedstocks. J. Soil Sediments 2016, 16, 177-190. [CrossRef]

145. Jien, S.; Wang, C. Effects of biochar on soil properties and erosion potential in a highly weathered soil. Catena 2014, 110, 225-233. [CrossRef]

146. Agegnehu, G.; Bass, A.; Nelson, P.; Bird, M. Benefits of biochar, compost and biochar-compost for soil quality, maize yield and greenhouse gas emissions in a tropical agricultural soil. Sci. Total Environ. 2016, 543, $295-306$. [CrossRef]

147. Das, O.; Sarmah, A. The love-hate relationship of pyrolysis biochar and water: A perspective. Sci. Total Environ. 2015, 512/513, 682-685. [CrossRef]

148. Cayuela, M.; Van Zwieten, L.; Singh, B.; Jeffery, S.; Roig, A.; Sanchez-Monedero, M.A. Biochar's role in mitigating soil nitrous oxide emissions: A review and meta-analysis. Agric. Ecosyst. Environ. 2014, 191, 5-16. [CrossRef]

149. Ameloot, N.; De Neve, S.; Jegajeevagan, K.; Yildiz, G.; Buchan, D.; Funkuin, Y.N.; Prins, W.; Bouckaert, L.; Sleutel, S. Short-term $\mathrm{CO}_{2}$ and $\mathrm{N}_{2} \mathrm{O}$ emissions and microbial properties of biochar amended sandy loam soils. Soil Biol. Biochem. 2013, 57, 401-410. [CrossRef]

150. Ameloot, N.; Sleutel, S.; Das, K.C.; Kanagaratnam, J.; De Neve, S. Biochar amendment to soils with contrasting organic matter level: Effects on $\mathrm{N}$ mineralization and biological soil properties. GCB Bioenergy 2015, 7, 135-144. [CrossRef]

151. Jones, D.L.; Rousk, J.; Edwards-Jones, G.; DeLuca, T.H.; Murphy, D.V. Biochar-mediated changes in soil quality and plant growth in a three year field trial. Soil Biol. Biochem. 2012, 45, 113-124. [CrossRef]

152. Gomez, J.D.; Denef, K.; Stewart, C.E.; Zheng, J.; Cotrufo, M.F. Biochar addition rate influences soil microbial abundance and activity in temperate soils. Eur. J. Soil Sci. 2014, 65, 28-39. [CrossRef]

(C) 2019 by the authors. Licensee MDPI, Basel, Switzerland. This article is an open access article distributed under the terms and conditions of the Creative Commons Attribution (CC BY) license (http:/ / creativecommons.org/licenses/by/4.0/). 